Heidegger on Freedom: Political not Metaphysical

Author(s): Leslie Paul Thiele

Source: The American Political Science Review, Vol. 88, No. 2, (Jun., 1994), pp. 278-291

Published by: American Political Science Association

Stable URL: http://www.jstor.org/stable/2944703

Accessed: 16/08/2008 09:40

Your use of the JSTOR archive indicates your acceptance of JSTOR's Terms and Conditions of Use, available at http://www.jstor.org/page/info/about/policies/terms.jsp. JSTOR's Terms and Conditions of Use provides, in part, that unless you have obtained prior permission, you may not download an entire issue of a journal or multiple copies of articles, and you may use content in the JSTOR archive only for your personal, non-commercial use.

Please contact the publisher regarding any further use of this work. Publisher contact information may be obtained at http://www.jstor.org/action/showPublisher?publisherCode=apsa.

Each copy of any part of a JSTOR transmission must contain the same copyright notice that appears on the screen or printed page of such transmission.

JSTOR is a not-for-profit organization founded in 1995 to build trusted digital archives for scholarship. We work with the scholarly community to preserve their work and the materials they rely upon, and to build a common research platform that promotes the discovery and use of these resources. For more information about JSTOR, please contact support@jstor.org. 


\title{
HEIDEGGER ON FREEDOM: POLITICAL NOT METAPHYSICAL
}

\section{LESLIE PAUL THIELE University of Florida}

\begin{abstract}
7 This essay analyzes modern and postmodern concepts of freedom and contrasts them to a Heideggerian understanding. Positive, negative, and what might be called Foucaultian or Nietzschean liberty are demonstrated to bear a common trait. In such modern and postmodern formulations, freedom is consistently identified with a form of mastery. This identification of freedom with mastery, I argue, encourages ecological abuse, supports the dangerous prerogatives of statist sovereignty, and strengthens the resilience of patriarchy. The political significance of Heidegger's alternative vision is addressed.
\end{abstract}

$\mathbf{I}$ n 1958, Isaiah Berlin delivered his now famous essay "Two Concepts of Liberty" (Berlin 1969, Chap. 3). From the hundreds of senses of the words liberty and freedom that historians of ideas have recorded, Berlin selects two for analysis: "positive" and "negative" liberty. Such timely conceptual distinctions, Berlin insists, have significant political ramifications. Attending to ideas in order critically to assess their meaning may prevent their acquiring an "unchecked momentum and an irresistible power over multitudes of men that may grow too violent to be affected by rational criticism" (p. 119). Berlin is reflecting on Heine's observation of the relationship between Rousseau's thought and Robespierre's deeds and on Heine's prediction that the romanticism of Fichte and Schelling might one day turn the Germans against the liberal culture of the West. More to the point, Berlin had the then closing Iron Curtain on his mind, and he would critically evaluate positive liberty as its ideological foundation.

With a similar concern for the social and political effects of our thinking, I propose to reexamine the concept of liberty. My worry, however, is not with past fascist threats or looming totalitarian menaces to liberalism. I am more concerned with liberalism's very success. To be specific, I am worried about the danger posed to our social and political life, our world and our earth, by the prevalent notions of freedom that underlie Western political culture. My intent here is not to add to the prodigious debate surrounding Berlin's seminal essay but to employ his rather facile schema, without the criticism it deserves, for other purposes. The analysis will not offset positive with negative liberty, but positive liberty, negative liberty, and their postmodern counterpart, with an understanding of freedom for which Martin Heidegger serves as the spokesperson.

Heidegger is seldom acknowledged for his concern with freedom. There are chiefly two reasons. First, Heidegger articulates freedom in a way that takes us beyond traditional formulations-formulations to which he remains consistently critical. As such, either his discussions are considered overly idiosyncratic and hence irrelevant to standard debates or his perspective (particularly given his understanding of technology) is held to leave little room for liberty of any ilk. Assessing Heidegger's relation to freedom as the Western world's preeminent political value, one recent commentator would thus dismiss him out of hand, observing curtly, "You can't be a very effective spokesman for freedom when your philosophy tells you that it doesn't exist" (Crews 1992, 33). I believe, however, that freedom constitutes the core of Heidegger's thought. ${ }^{1}$ Indeed, Heidegger himself insists that "the question of the essence of human freedom is the fundamental question of philosophy, with even the question of Being entwined in it" (Heidegger 1976-89, 31:300). What follows is an effort to demonstrate the meaning and political relevance of this claim.

The second reason accounting for the frequent dismissal of Heidegger's contribution to our understanding of freedom is his own political biography. For many, Heidegger's work is irredeemably tarnished by his fervent support of national socialism while serving as rector of Freiburg University beginning in 1933 and by his stubborn reluctance after the war to come to terms with the meaning of this involvement. Heidegger's political biography and its relation to his philosophy has proven material for volumes of discussion and diatribe. Here I have chosen to skirt this issue-maintaining a theorist's prerogative to derive from a philosophy political sensibilities that its author has not earned and might well disown. The political implications I draw from Heidegger's understanding of freedom, to be sure, are in conflict with the more infamous aspects of his life. Yet they are congruent, I would argue, with the thrust of his philosophy as a whole. Moreover, my effort remains faithful to the basic orientation of Heidegger's own investigations. In philosophy, Heidegger observes, discovering necessarily means shaping $(1985 a, 38)$. Like all works of interpretive political philosophy, mine shapes a certain world out of something discovered in another's text. My concern, then, is not "with 'Heidegger', but with what he thinks about" (Blitz 1981, 16). I argue that in thinking about human freedom, Heidegger, after some missteps, demonstrates the need for a fundamental rearticulation of what in the West we find most essential to our historical and political being. How to voice this rearticulation of freedom within 
one's own political life is, of course, neither for Heidegger nor for his biographers to decide.

\section{FREEDOM-NEGATIVE, POSITIVE, AND POSTMODERN}

Negative liberty, simply put, is freedom from constraint. It signifies the (political) space accorded the individual to pursue desires unhindered by the impositions of others. Its particulary modern formulation, stemming from the Renaissance and Reformation, is the notion of privacy-a sacrosanct area of personal freedom over which the individual has complete jurisdiction and which demands protection from all external interference, whether that of the church, state, or society. Negative liberty denotes the individual's unchallenged control over his immediate environment, enabling the exclusion of others from its trespassing. Berlin identifies negative liberty as the core of liberalism. Positive liberty, in contrast, is not a freedom from but a freedom to. It denotes a freedom to do. But positive liberty entails doing not only what one desires, unhindered by external constraints, but what one should desire, unhindered by internal constraints such as irrational drives, weaknesses of character, false consciousness, or even shortsighted judgment. Free will is only truly free, in other words, when it actualizes the individual's "objective" interests. Hence, positive liberty necessitates both the discovery of one's proper needs or desires and the capacity to see them fulfilled. If, with Rousseau, we discover our true interests to coincide with the general will, then we may find ourselves in the curious position of being forced to be positively free. If, with Marx, we find our true interests to be determined by our nature as species beings, then attaining positive liberty consists in achieving radical equality and fraternity such that each gives according to his abilities and receives according to his needs. And finally, if, with the Nazi ideologues, we hold our true interests to lie with the expansion and rise to power of the Volk, then we may experience our positive liberty only in the life and death struggle for Lebensraum. Positive liberty, in short, is freedom to be the most one can be. Attaining this goal-often a group effort-entails both the discovery of one's higher self and the extension of its mastery over one's lower (deluded) self. ${ }^{2}$ Berlin therefore identifies positive liberty with self-mastery. As an isolated ideal, selfmastery would appear difficult to disparage. The problem is that the selves being mastered within the social whole are generally understood to be identical in desires, needs, and reason. Historically, Berlin notes, the quest for positive liberty has therefore led to a "prescribed form of life" that often serves as "a specious disguise for brutal tyranny" (1969, 131).

Berlin, it comes as no surprise, opts for negative liberty. He advocates for the pluralism it assumes and fosters. Positive liberty, he acknowledges, has its place, but it is a place of subordination to its negative counterpart. The positive liberty to participate in government is consequently identified not as an end-in-itself (citizens' realizing their full political nature) but rather as the only tried and true means of protecting negative liberties. Here Berlin appears to echo Samuel Johnson's reported view that "political liberty is good only so far as it produces private liberty" (Boswell 1979, 140). Yet Berlin is not a radical libertarian. He means to argue against the conflation of meanings and values, and he deprecates the tendency to place negative liberty upon an unassailable pedestal. Freedom is freedom, and it is good. But it is not the only value we have or should have. Justice is also good, and its instantiation might at time require a diminution of (negative) liberty. To underline the point, Berlin observes that we force children to go to school. In so doing, we constrain their freedom for the purpose of elevating another value, namely the diminution of ignorance. To say that in forcing children to attend school we are not actually curtailing their freedom because their freedom is effectively increased by the growth of their knowledge (of possible choices to be made, etc.) is only dangerously to conflate the meanings of positive and negative liberty. ${ }^{3}$ One senses that in this regard Berlin would agree with Edmund Burke. "Liberty," Burke writes in his "Letter to the Sheriffs of Bristol," must be limited in order to be possessed" (Burke 1960, 211).

The concepts of negative and positive liberty, Berlin proposes, gave rise to "the great clash of ideologies" that dominated his time. In 1958, Berlin could write that the view of those who reject negative liberty and favor its positive counterpart "rules over half our world" $(1969,138,141)$. Concerns are significantly different today. History has rerouted the Marxist yearnings for positive liberty and swept away their institutional perversions. Moreover, as if the momentous political events of our times were not enough, events within the intellectual community have further undermined the viability of positive liberty. Whereas Berlin feared that the rational self was endangered by collective prescriptions for its mastery, postmodernists have declared this self an outright fiction. The notion of a fixed rationality that typically grounded the search for a mastered self has become thoroughly suspect. Rationalities may exist but not $a$ rationality that transcends culture, gender, history and power. In the postmodern world, the rational self has been deconstructed. The pursuit of positive liberty is thus set adrift without anchor. But the postmodern world has left negative liberty in equally dire straits. As Michel Foucault best demonstrates, contemporary power does not limit itself to prohibiting the fulfillment of desires: it engages in the stimulation and production of desire itself. Power, Foucault insists, should no longer be viewed solely as a juridical and repressive force, symbolized by a king who constrains the movements of his subjects. Increasingly, biopower manifests itself as an insidiously creative force, evidenced in the social and political apparatuses and technological networks that shape lives (see Thiele 1986). The postmodern worry is that 
both the individual and the social body have become the vehicles and chief effects of power-objects of stimulation, manipulation, and production. Power today is in the business of creating subjects, not merely constraining them.

Berlin affirms that negative liberty entails an actual political or public space within which unconstrained thought and action may occur. Freedom is not simply the ability to do as one wishes-a faulty conclusion Berlin attributes to John Stuart Mill. Berlin reasons that if freedom is a function only of desire and not of (external) empirical possibility, then any contraction of desire becomes ipso facto an increase in freedom. His worry is that tyrants could suppress us to the extent that certain desires would atrophy. Under the desire-dependent definition of negative liberty, we would then be considered free(r) because we would feel ourselves to free(r), expressing little or no inclination for abolished political spaces, opportunities, and rights. Freedom-Berlin might have paraphrased Rosa Luxemburg - is truly freedom only if it allows one actually to think, speak, or act differently. The point is well taken. Any political freedom worth its name must allow for the thinking and saying-and to a lesser extent the doing - of what contests the popular and the prescribed. But the postmodern world presents a more complex picture, which, while not obviating the perennial concern of linking liberty to opportunity, casts any straightforward relationship in doubt. Not only the repression of desire but its manipulation and hyperproduction are increasingly in evidence today. The image Berlin supplies to illustrate his point is that of the ascetic philosopherslave Epictetus, who mistakenly imagines himself free because he has learned severely to restrict his wants. If we are to hark back to first-century Rome for illustrations of contemporary threats to liberty, however, then the debauched Nero perhaps better serves our purpose. A surfeit of desire and seduction that militates against meaningful community and politics better limns the dangers of postmodern (Western) patterns of unrestrained production and mediadriven consumption. Our subjectification in a technological world-the administration of our identities as desirers, producers, and consumers-is insufficiently addressed by the vocabulary of negative liberty.

How, then, are we to formulate the question of liberty in the postmodern world, supplanting or supplementing the negative liberty which allows personal control over a private domain? Michel Foucault calls for resistance to the productive forces of power that manipulate and produce our identities. Freedom today, he maintains, is to be discovered in the ongoing struggle against the techniques of subjectification. Foucault insists that freedom is less a thing to be secured, like the individual rights and opportunities of Berlin's negative liberty, than an activity to be engaged. "Liberty," Foucault insists, "is a practice," it is "what must be exercised" $(1984,245)$. With this in mind, Foucault preferred not to speak of an "essential freedom" to be safeguarded so much as an "agonism" inherent in all social and political relations $(1983,222)$. For Rousseau (and to a certain extent for Cicero, Montesquieu, Locke, and Kant), freedom entailed subordination to a law of one's own making. Foucault adopts the Nietzschean premise that the self, not solely the law, must be of one's own making. With the self no longer given (as the gift of God, nature, or history), freedom is manifest only through its "invention." Hence, we are admonished "to create ourselves as a work of art" (1980, 10-11; 1983, 237). Foucault, however, insists that freedom of the creative self arises only in the social and political arenas wherein our identities become the spoils of battle. His genealogical efforts to destabilize and contest modern modes of subjectification are consequently aimed at giving "new impetus, as far and wide as possible, to the undefined work of freedom" $(1984,46)$. Effectively, Foucault politicizes Nietzsche's philosophic struggle of self-invention.

Foucault's understanding of freedom bears features of both negative and positive liberty. Foucault adopts the "exercise concept" of positive liberty, wherein freedom is found not in the absence of external hindrances (the "opportunity concept" of negative liberty) but in an activity itself. ${ }^{4}$ For Foucault, however, this activity is not tantamount to the actualization of a true or higher self. Like the negative libertarians, he resists defending the nature of freedom or its practice as a function of the individual's completed (rational, moral, or political) development. Foucaultian freedom entails the struggle to remain free from definitions of the self that prescribe its telos. Rather, freedom is found in the construction of a protean self as it evolves by way of the dynamic clash of productive power and resistance. Let us call this Foucaultian (and Nietzschean) understanding of freedom the postmodern concept of liberty. In contrast to the freedom from (constraints) of negative liberty and the freedom to (master a rationally or collectively defined self) of positive liberty, postmodern liberty might be thought of as a freedom in. Primarily, this freedom is actualized in the struggle of self-creation. As a student of Nietzsche's tragic school of thought, Foucault celebrates this freedom in the seemingly futile and endless attempt to create a self that necessarily remains forever enmeshed in webs of power. Hence, Foucault calls for a "hyper- and pessimistic activism" $(1983,232)$. Postmodern liberty, by this count, is found in the heroic endeavor to create a self as a work of art, or it is not found at all.

Commenting on Berlin's thesis, Alan Ryan notes, "The simplest characterization of positive libertarians is that they identify freedom with control" $(1979,5)$. Ryan's remark is apt, for positive liberty refers to (one's higher self's) control of one's desires, needs, and (ultimately) of one's world. What Ryan fails to observe, however, is that negative libertarians are also animated by a pursuit of control. For negative liberty, we recall, identifies the individual's control of his immediate environment, of his private life and space. The key difference is that for negative libertarians, sovereignty is limited to a putatively personal 
realm of objects and relations. While positive libertarians advocate mastery of a transcendent self through collectively mediated, self-given law, negative libertarians advocate mastery of an empirical self over a private domain. According to Foucault and postmodern thinkers in general, the transcendent self is too mythical and the empirical self too malleable for positive and negative concepts of liberty to cut much ice-hence the need for self-invention, a creative resistance to the productive power that envelopes us. But herein, I would argue, postmodern liberty displays its greatest affinity to positive and negative liberty by way of its own, rather subtle pursuit of control.

The postmodern liberation from teleological ends is achieved only by way of the subject's reinvestment in an ideal of artistic mastery. The mastery of the ungrounded but creative self over its own constitution now becomes the Sisyphean task. This move is perhaps best understood as the postmodern radicalization of the self-mastery sought by the Stoic philosophers, whom Berlin correctly identifies as epitomizing positive liberty and whom Foucault chooses to focus upon in his last works. Stoic self-mastery entails the disciplined sculpting of the self into an impervious image of natural law. Postmodern libertarians dismiss natural law (along with gods and transcendent norms). But the nucleus of the Stoic task remains intact. The postmodern attempt to mold the self into a work of art posits the self as a malleable object of production. The task, Foucault states, is to resist the hegemonic "techniques and practices" of power that have constituted the self in the West in order to chart the conditions of an alternative transformation $(1993,224)$. This autoconstitution of the self is to be achieved by means of the "stylized repetition of acts" (Butler 1990, 140). Fire must be fought with fire. We must become technicians of our own being-dandies of a sort-using our life to fashion ourselves into admirable aesthetic works. Admittedly, Foucault denies that this aesthetic self can gain complete sovereignty within the webs of contemporary biopower. Contingency is everywhere in evidence. Citing Nietzsche, Foucault acknowledges that the individual harbors "not an immortal soul but many mortal ones" and that these are "unable to be mastered by the powers of synthesis" $(1984,94)$. But, as with Nietzsche, the tragicoheroic effort is made nonetheless. Foucault would have us gain our freedom by moving beyond the "subjected sovereignties" of humanism-beyond "the subject as a pseudosovereign" - to a self whose true sovereignty is marked by the absence of inhibitions in the effort to define its identity $(1977,221-22)$. In the face of the ubiquitous threat of normalization, the postmodern retaliates with willful self-creation. Will-topower takes on the persona of the master artist turned upon himself even if, in postmodern times, he is a Picasso, rather than a Rembrandt.

Like William Connolly, I am arguing that "mastery is the route to freedom" for both "individualists" (negative libertarians) and "collectivists" (positive libertarians) $(1991,29)$. I differ from Connolly, however, in proposing a residual pursuit of mastery, albeit aestheticized, among the Nietzschean and Foucaultian theorists of freedom. ${ }^{5}$ Foucault, like most postmoderns, acknowledges his debt to Heidegger, who is claimed as the "essential philosopher" determining his "entire philosophical development." At the same time, Foucault recognizes that Nietzsche "outweighed" Heidegger in influence (1985, 8-9). My argument is that Foucault's understanding of freedom-like his work in general-evidences the burden of Nietzsche (see Thiele 1990, 1991). Despite the differences between positive liberty, negative liberty, and postmodern liberty (and there are many important differences indeed), the identification of freedom with mastery remains central to all. Moreover, whether the mastery in question is of the higher self over the lower self and its desires and needs (as with positive liberty); or the mastery of the empirically demonstrable self over its private domain (as with negative liberty); or the mastery of the aestheticagonistic self over its contested, protean constitution (as with postmodern liberty) - each form of liberty tends to loose its quest for mastery upon the world.

\section{FREEDOM-NOT METAPHYSICAL}

During his politically active career as rector of Freiburg University under the Nazi regime, Heidegger adopted a positive concept of liberty. In line with Nazi ideology, which he fervently propagated during his brief tenure, Heidegger situates the self within a Volk that circumscribes and defines its identity. Thus, Heidegger bore out Heine's prediction of German romanticism's turning the nation against liberal culture. Addressing the question of academic freedom after the imposition of the Nazi Gleichschaltung, which sought to organize students and faculty according to the Führerprinzip in an effort to integrate the university into the party and state, Rector Heidegger applauds the demise of negative liberty and celebrates its positive counterpart: "This will is a true will in that the German student body, through the new Student Law, places itself under the law of its own essence and in this way for the first time determines that essence. To give the law to oneself is the highest freedom. The much celebrated 'academic freedom' is being banished from the German university; for this freedom was not genuine, since it was only negative. It meant primarily freedom from concern, arbitrariness of intentions and inclinations, lack of restraint in what was done and left undone. The concept of the freedom of the German student is now brought back to its truth" $(1985 b, 475-76)$. Here positive freedom is found in subservience to a law of one's own making. But it is not the self as an individual who makes the law but the self as a member of an organic people. One wills the general will as it grows out of a folk and is given voice through the party and the Führer.

After his rectorship, Heidegger would scale back 
and eventually abandon his advocacy of a (folkish) positive liberty without, however, moving in the direction of negative liberty. He rejects both the latter notion of liberty as "unfettered arbitrariness" and the former notion of liberty as "the constraint of mere laws," including self-given laws $(1977 b, 25)$. Heidegger develops a new concept of freedom that effectively extends and reworks his prerectorial approach. By the early forties, he would write: "Freedom is not what common sense is content to let pass under that name: the random ability to do as we please, to go this way or that in our choice. Freedom is not licence in what we do or do not do. Nor, on the other hand, is freedom a mere readiness to do something requisite and necessary and thus in a sense 'actual'. Over and above all this ('negative' and 'positive' freedom) freedom is a participation in the revealment of what-is-as-such" $(1949,307)$. In important respects, this understanding of freedom resembles Nietzsche's and Foucault's. Heidegger now posits freedom as an activity, event, or happening. Importantly, however, he rejects the postmodern notion of liberty as the mastery of a creative, artistic self. Rather, freedom is proposed as a disclosive "letting-be." I shall argue that Heidegger's development of this disclosive freedom presents us with more than just another philosophical profile of a concept already overburdened with meanings. Heidegger's mature understanding of freedom is radically distinct from its modern, metaphysical forerunners and their postmodern derivations; for it offers dignity in a freedom that celebrates guardianship rather than mastery.

Let us begin with a rehearsal of the key features of Heidegger's understanding of human being (Dasein). In distinction to all other beings, human being is interrogatively occupied with its own existence. Existing (as an ontic or factual category) is something humans share with all beings. Only human being, however, is ontologically disposed to its life, orienting itself in questioning to its own being. In questioning the Being of its own being, human being cannot help but question that which serves as the ground for all being, for beings as a whole. In short, Heidegger understands human being as that for which Being itself, the Being of beings (das Sein des Seienden), comes into question. He writes in Being and Time: "Dasein is an entity which does not just occur among other entities. Rather it is ontically distinguished by the fact that, in its very Being, that Being is an issue for it ... Understanding of Being is itself a definite characteristic of Dasein's Being. Dasein is ontically distinctive in that it is ontological" $(1962,32)$. The distinctiveness of human being is not self-consciousness but consciousness of a self that questions its own ground, and ipso facto questions the ground of being in general.

Metaphysics, beginning with Plato's theory of the forms, projects Being as an enduring and unchanging thing. As such it may be represented, by an idea, in our minds. Rejecting this metaphysical orientation, Heidegger proposes Being as nonrepresentable. It is tentatively defined as unconcealment or presencing. We never actually perceive unconcealment or presencing. What is directly available to human being are beings, that which is present-at-hand and ready-tohand. The actual presencing of that which is present remains hidden and is made available only by ontological questioning. The essence of human being, then, is the provision of a place for Being to become manifest as the questionable and hidden ground of all that is. Heidegger adds that the unconcealedness of beings is a "happening" $(1971,54)$. Human being is the site of this happening. Dasein, we remember, literally means "there-being." Human being is the there where the happening of the disclosure of Being (as nothingness) occurs. In this sense, human being may be posited (to employ Heidegger's locution) as the "abode" of Being (1981, 244). Perhaps better, human being is an abode in preparation for Being, an "openness." In human openness, Being becomes manifest-not as some newly discovered thing that lies before us (as a object) or within us (as an idea or form) but as the mystery of its own hiddenness within beings. Because Being reveals itself only through human being, Heidegger dubs human being the persona, or "mask," of Being $(1968,62)$. Only through its mask is Being's presencing discerned. Hence, within the openness of human being, Being shows itself as masked. Outside the openness of human being, Being does not come to presence (as masked) at all.

In distinction to all metaphysical theorizing, Heidegger insists that Being is not something primarily of substance or form. Being is not a thing at all, but the no-thing - "the pure 'Other' than what-is" - that grounds all things (Heidegger 1949, 360). Even if we could rip away the mask of Being, therefore, no discernible features would be revealed lying beneath; for Being is nothing extant. Yet it is precisely the disclosure of Being's no-thingness or hiddenness that human being assumes as its essential task. Heidegger explains by way of a visual metaphor: "Everyday opinion sees in the shadow only the lack of light, if not light's complete denial. In truth, however, the shadow is a manifest, though impenetrable, testimony to the concealed emitting of light. In keeping with this concept of shadow, we experience the incalculable as that which, withdrawn from representation, is nevertheless manifest in whatever is, pointing to Being, which remains concealed" (1977b, 154). As I shall argue, freedom is also experienced as that which, though nonrepresentable, is nonetheless manifest in our capacity to disclose the hidden Being of beings.

Shadows offer the necessary contrast and background for that which is lit. What remains in concealment allows the unconcealed its distinctiveness. It follows that the illuminated opening of human being is largely defined by its shadows. Heidegger understands the perimeter marking the boundaries of our disclosive capacities to be intrinsic to human being and human freedom. Dissociating his from a common understanding of freedom as unrestricted move- 
ment, he writes: "It is misguided to think one understands freedom most purely in its essence if one isolates it as a free-floating arbitrariness. Moreover, the task is precisely the reverse, to conceive freedom in its finitude and to see that, by proving boundedness, one has neither impaired freedom nor curtailed its essence" (Heidegger 1984, 196). Every act of freedom is a foreclosing of alternatives and possibilities. Freedom, therefore, is not an unbounded and ungrounded power to do, move, or create. Rather, freedom is freedom to reveal what is. But what is, most fundamentally, comes to presence only insofar as it remains illuminated in contrast to what remains hidden. In other words, only the no-thing that is Being allows human being the disclosure of beings or things. In this tensioned disclosure, freedom pertains: "Without the original manifest character of Nothing there is no self-hood and no freedom. . . . Nothing is that which makes the revelation of what-is as such possible for our human existence" (Hiedegger 1949, 339-40). Human being displays its freedom to the extent that it remains open to the inexhaustible mystery of Being in its bounded disclosure of beings. Heidegger writes: "Freedom is the condition of possibility of the disclosure of the Being of beings, of the understanding of Being." (Heidegger 1976-89, 31:303).

Heidegger, particularly in his early writings, referred to the openness of Dasein with the term resoluteness (Entschlossenheit, lit. "unclosedness"). Heidegger's commentators have often taken his early concern with resoluteness to imply a hard-willed, decisionistic orientation-a Nietzschean or existentialist enamoredness with the power to fashion one's world, where, as Sartre observes, one is "condemned to be free" owing to the burden of total responsibility for the self that one shoulders. Yet the notion of resoluteness, Heidegger at least retrospectively affirms, does not imply Promethean choices. Indeed, it marks the renouncing of such willfulness: "The resoluteness intended in Being and Time is not the deliberate action of a subject, but the opening up of human being, out of its captivity in that which is, to the openness of Being" (Heidegger 1971, 67). Hence, Heidegger maintains that "to question is to will to know. He who wills, he who puts his whole existence into a will, is resolved. . . . But the essence of resolve lies in the opening, the coming-out-of-cover of human being-there into the clearing of being ... its relation to being is one of letting-be" (1987, 20-21). The name Heidegger gives to the resolute willing of openness to Being is Gelassenheit, a term borrowed from Meister Eckhardt that literally means "lettingbe" or "releasement." Human freedom, for Heidegger, particularly after his "turning" of the mid-1930s, is fundamentally and foremost a letting-be. ${ }^{6}$

Openess to Being is effectively an opening of the self to the fundamental interrogation of (its) being. This resolute openness manifests human freedom, for to be occupied with the question of one's own being means "to understand oneself in one's own factual freedom" (Heidegger 1982, 276). This is not to say, however, that human freedom is equivalent to self-absorption. As Heidegger makes clear, we are speaking of the concern for oneself as a human being, that is, as a being-in-the-world-with-others: "To be free is to understand oneself from out of one's own capacity-to-be; but 'oneself' and 'one's own' are not understood individually or egoistically. . . . They are understood in the basic possibilities of transcending Dasein, in the capacity-to-be-with with others, in the capacity-to-be by extant things" $(1984,214)$. In making its own being an issue, human being opens itself to the question of beings as a whole, which entails opening itself interrogatively to a populated world. Now fundamentally to interrogate this world demands a forgoing of pervasive efforts at its mastery; for fundamental questioning ceases the moment the presumptions and prejudices that necessarily precede such attempts at domination or control arise. To be sure, the disclosure of Being ensues from all human activities and experiences, including human efforts at attaining mastery. But herein Being, as well as the nature of human freedom, becomes obscured. It is revealed only as forgotten. To reveal something as forgotten is to reveal something as no longer in question, as no longer fundamentally questionable. That we are, as Heidegger states, called upon to be the shepherds of Being indicates that we find our freedom not in a forgetful mastery but in a mindful, interrogative caretaking, in concernfully and questioningly letting the Being of beings be. Freedom is therefore most primordially manifest in our care-full being-in-the-world-with-others.

Disclosive freedom, Heidegger insists, is not merely one value among others. Nor either, is freedom a metavalue, the "value of all values" that allows one to choose between and secure other values (Cranston, 1967, 42). "Freedom," Heidegger writes,

is not a particular thing among others, not something lined up as part of a row, but rather it prescribes and permeates the totality of beings as a whole. If we are to investigate freedom as the ground of possibility of human being, then its essence is more primordial than man. Man is only a guardian of freedom, . . . human freedom signifies now no longer: freedom as a property of man, but the reverse: man as a possibility of freedom. Human freedom is the freedom which invades and sustains man, thereby rendering man possible. (1976-89, 31:134-135; see also 1985a, 9)

Traditional Western thinking posits freedom as the autonomous subject's most valued asset, as its capacity to define and control what it confronts. Heidegger, contrariwise, understands freedom as that which exposes human being to the undefinable and unmasterable, to Being. But what is beyond one's power to master or define is also beyond one's power to calculate and assess. Freedom, therefore, is that unique capacity of human being that allows a reaching beyond calculation and valuation.

Heidegger observes that

through the characterization of something as "a value" what is so valued is robbed of its worth. That is to say, by the assessment of something as a value what is valued is admitted only as an object of man's estimation. But what 
a thing is in its Being is not exhausted by its being an object. ... Every valuing, even where it values positively, is a subjectivizing. It does not let beings: be. Rather, valuing lets beings: be valid-solely as the objects of its doing ... When one proclaims "God" the altogether "highest value," this is a degradation of God's essence. Here, as elsewhere, thinking in values is the greatest blasphemy imaginable against Being. $(1976,228)$

Everything Heidegger says here of God or Being might also be said of freedom. Once freedom becomes a value-even the highest value-it ceases to identify that which enables us to partake of the mystery of Being. Subjecting freedom to metaphysical or representational thought-allowing its designation as a value-is an effective assertion of the self's capacity to evaluate and control its relation to Being conceptually if not physically. According to Heidegger, however, "freedom's incomprehensibility consists in the fact that it resists com-prehension ... because freedom transposes us into the occurrence of Being, not in the mere representation of it" (1985a, 162). Freedom is the gift that allows human being to glance beyond the self-beyond being and its mastery in thought, word, or deed. For Heidegger-and in stark contrast to the Western metaphysical tradition-freedom is not a value, but beyond valuation; freedom is evidenced not in decisionistic willfulness but through careful nonwilling; freedom is not an unbounded power to do but a discovery and disclosing of one's place within bounds.

\section{FREEDOM-POLITICAL}

There is no direct, unavoidable and obvious translation of Heidegger's ontological perspective on freedom into a specific political practise. At the same time, our self-understandings as individuals and members of collectivities have important political ramifications. In attempting to answer the question, What shall be done? the discovering and maintaining of a sense of self becomes an essential part of any doing. Our actions in the world stem from, feed into, and flow through our identities. If, then, we accept with Heidegger that "the highest dignity of [man's] essence... lies in keeping watch over the unconcealment-and with it, from the first, the concealment-of all coming to presence on this earth" $(1977 b, 32)$, it follows that our daily comportment would reflect a certain worldly solicitude. Were modern humanity to discover its dignity in freedom understood as an interrogative disclosure rather than a willful mastery, then significant changes in political culture would be foreseen.

Humanity is now threatened by the ecological limits of a world that it has unceasingly sought to master. I am suggesting that the dangerous selfconfidence expressed in humanity's technological exploitation of itself and its world is at least partly explained by the fact that human freedom has been consistently equated with the power to control. Freedom continues to be the Western world's most cherished value. Any change on that score seems unlikely. The political relevance of Heidegger's philosophy is that it allows us to maintain our love of freedom while reining in its more pernicious effects. My argument is not that we must reject out of hand hard-won and still insufficiently propagated positive and negative liberties nor that we must completely shun the aestheticized liberty of postmodern times. But we do need to recognize the significance of disclosive freedom. The task, in other words, is not to bury the past and its achievements but to recognize their dangers while preparing to receive the future. And our future as a species appears doubtful indeed if human dignity can be experienced in nothing but mastery.

Still, the Heideggerian alternative may appear all too passive for many. For does not disclosive freedom reduce us to impotent observers of fate? Is it not simply a recipe for lassitude at the end of humanity's turbulent history of ingenuity, creativity, and destruction? If so, then such freedom would be (as the ballad says) "just another word for nothing left to lose" and nothing to be done. Saint Augustine declared it a great liberty to be able not to sin and a greater liberty to be unable to sin. Heidegger believed that there is indeed much freedom in being able not to will. But he insists that there is no freedom gained in being unable to will. To escape willful mastery, a resolute will is still necessary. Great effort is required (to prepare the self) to let beings be. Just as freedom in resoluteness is not arbitrary willfulness, so freedom in letting-be is not a doing nothing. Disclosive freedom is always the freedom resolutely to will openness to Being. And this openness does not preclude but rather invites human activity and intellect. In turn, letting-be is not tantamount to abandonment of the world or isolation of the self. Quite the opposite: it entails the formation of dynamic worldly relationships, relationships all the more dynamic because they are no longer constrained by the limitations of a subject/object dichotomy.

Heidegger writes: "the freedom to reveal something overt lets whatever 'is' at the moment be what it is. Freedom reveals itself as the 'letting-be' of what-is. The phrase we are now using, namely the 'letting-be' of what-is, does not, however, refer to indifference and neglect, but to the very opposite of them. To let something be is in fact to have something to do with it. . . . To let what-is be what it is means participating in something overt and its overtness" (1949, 305-6). "To free," Heidegger observes elsewhere, "really means to spare. The sparing itself consists not only in the fact that we do not harm the one whom we spare. Real sparing is something positive and takes place when we leave something beforehand in its own nature, when we return it specifically to its being, when we 'free' it in the real sense of the word into a preserve of peace" $(1971,149)$. The practice of freedom, then, is not the passivity of the fatalist. Indeed, Heidegger distinguishes between fate (Schicksal) and destiny (Geschick). Fate compels us to the "inevitableness of an unalterable course"; but nothing in this 
world, not even the dominance of modern technology, is a fate for human being (Heidegger 1977b, 25). Rather, the historical disclosure of Being, including its current form as technological enframing (Gestell), is a destining. Destiny does not compel, it calls. Human freedom is evidenced in the listening and responding to the destining of Being, which calls us actively to participate in revealing. There is no question of blind obedience, nor is resignation our appointed lot. And the reason, Heidegger states explicitly, is that we are free. ${ }^{7}$ The experience of beings in their Being, which for Heidegger delimits the realm of human freedom, should frame our disposition neither pessimistically nor optimistically. Most fundamentally, it yields a tragic experience, that is to say, an experience of resolute action tempered by the wise recognition of limits (Heidegger 1975, 44).

The problem, then, is not the diminution of our creative forces as a species. The problem is that historically these forces have far too often been exercised in the struggle for mastery and domination. This, I believe, is the proper response to critics who interpret Heidegger to promote a sort of political quietism. The typical question is, "How can we think of democracy without imputing to man the minimal will and mastery that Heidegger denies him because will and mastery in some sense already contain the seeds of the world of technology conceived of as the "will to will?" (Ferry and Renaut 1990, 17). The answer is straightforward: Heidegger does not deny human being a "minimal" will and mastery, but he does seek to constrain its unbridled hegemony in the modern world.

The explicitly political nature of Heidegger's understanding of freedom (to repeat) is not unequivocal. One might say that it is political by default, in that its antimetaphysical nature leaves it no better characterization. Alternatively, its political import might best be demonstrated by its capacity meaningfully (though not univocally) to address current political concerns, such as the need for environmental care and technological restraint, the dangerous prerogatives of national sovereignty, the distinctions between public and private concerns, and the development of a nonpatriarchal society. I shall attempt to illustrate my point by critically examining some of the support Heidegger's notion of disclosive freedom finds-and gives- to more explicitly political theorizing.

\section{Disclosive Freedom and Ecological Politics}

Freedom in the Western tradition has been identified since Adam with dominion over the earth, and there is little in positive and negative liberty (or its postmodern counterpart) that militates against this. Historically, positive libertarians have celebrated the domination of nature as a testimony to the prerogatives of human rationality. Like the domination of the lower self (or of "inferior" peoples and classes), the domination of the earth often serves positive libertarians as an attestation of human freedom. Negative libertarians, in turn, have fostered such domination in no less degree owing to their preoccupation with the exclusive personal rights of property. Nature, incapable of bearing rights of its own, relinquishes all claim to protection, respect, or care to the extent it is not accorded sanctuary under the aegis of private property. But private property-understood in a Lockean sense as the extension of the self('s labor)-is to be disposed of as its owner sees fit, unconstrained by anything save perhaps the obligation of efficient exploitation. (Thus Locke would justify the expropiation of native American lands without recompense owing to the natives' inadequate exploitation of them. According to Locke, leaving lands unexploited was equivalent to wasting them. And in wasting their lands, the natives forfeited all rights of ownership and defense [Locke 1960, 336-7; see also Glausser 1990].) Postmodern liberty has been around too short a time to have earned any historical indictment on ecological grounds. Yet my sense is that postmodern liberty, which valorizes the powers of artistic creation and heroic struggle, is more likely to depreciate than celebrate qualities of guardianship. The justifiable postmodern concern with the panoptic social administration of selves has a tendency to foster a radically individualistic (even narcissistic) reaction. With the primary postmodern worry being the dangerous encroachments of "pastoral power," any linking of freedom to stewardship would prove problematic (Foucault 1979, 1981). In short, without an understanding of liberty divorced from the will to mastery, the postmodern struggle against subjectification is as unlikely as negative or positive liberty to result in a worldly caring.

Heidegger's philosophy of freedom, on the other hand, buttresses ecological concerns at large. Michael Zimmerman writes that

Heidegger's critique of anthropocentric humanism, his call for humanity to learn to "let things be," his notion that humanity is involved in a "play" or "dance" with earth, sky, and gods, his meditation of the possibility of an authentic mode of "dwelling" on the earth, his complaint that industrial technology is laying waste to the earth, his emphasis on the importance of local place and "homeland," his claim that humanity should guard and preserve things, instead of dominating them-all these aspects of Heidegger's thought help to support the claim that he is a major deep ecological theorist. (1990, $242-43)^{8}$

There is much to what Zimmerman says here, and one might add to his list Heidegger's understanding of Dasein as care and his definition of human being as the "shepherd of Being." However, one must be wary of straightforward translations of Heideggerian philosophy into ecological practice. For human being, Heidegger insists, is not the shepherd of beings (i.e., the guardian of natural life) but the shepherd of Being. Such guardianship, Heidegger explicitly states, "is not fixated upon something existent" (1971, 184). In turn, while Heidegger does suggest that truth (Wahrheit) is to be experienced as preservation and that "preservation belongs to the herds- 
man," he is also quick to point out that this understanding has "little to do with bucolic idylls and Nature mysticism"; for being a herdsman is only possible if one "continues to hold the place of nothingness." Quite out of keeping with romanticized visions of a seamless pastoral life, the shepherding of Being places one anxiously on the abyss of groundlessness. In short, Heidegger's is a ontological, not a naturalistic, project. A questioning relation to Being may indeed erupt from a solicitous wonder at the vast diversity and beauty of a natural ecosystem. But it may also result from gazing at stars, studying quantum physics, or raising a child in the inner city.

Heidegger, as Zimmerman notes, supports a nonanthropocentric approach to the earth and world. This is absolutely true and has obvious ecological merit. But Heidegger does not suggest the replacement of anthropocentrism with biocentrism-a belief, held by deep ecologists, that relegates the human species the same status as all other organisms. ${ }^{9}$ Despite his fervent attack on subjectivism and humanism, Heidegger firmly maintains human exceptionalism on account of the human capacity for freedom: "The question of Being and its variations and possibilities is at heart the correctly understood question of man. Compared with the duration of cosmic galaxies, human existence and its history is certainly quite fleeting, only a 'moment'. But this transiency is nevertheless the highest mode of Being when it becomes an existing out of and towards freedom" $(1984,18)$. Zimmerman hedges his praise of Heidegger's ecological credentials at this point, citing this passage as indication that Heidegger "overestimated our importance" compared to that of the rest of nature $(1983,121)$. But Zimmerman overlooks Heidegger's statement a few paragraphs earlier that such fundamental questioning is "far removed from any noisy self-importance concerning the life of one's own soul or that of others" $(1984,16-17)$. As a being that experiences freedom through its participation in the disclosure of all that is, human being does gain special status in Heidegger's universe. For the disclosive capacities of human beings are, so far as we know, unique: "It is man, open toward Being, who alone lets Being arrive as presence" (Heidegger 1969, 31-32; see also 1962, 28, 35). But Heidegger was explicit that the ontological priority and worthiness of human being in no way determines that the natural world - or the material world at large-exists (solely) for our benefit. ${ }^{10}$ Indeed, disclosive freedom flourishes only in the absence of such a possessive, egoistic, and utilitarian assumption. Human being is the highest being only to the extent that human being gains release from all self-aggrandizing subjectivism. If there is a claim of greatness to our being, then it arises not primarily from our mastery of the earth but from the unique human capacity to dwell and disclose in a way that preserves.

Along these lines, one might say that Heidegger supports what today would be called a bioregional approach to environmental care. He proposes that intimate ties to soil and locality serve as the antidote for the large-scale centralized manipulation and extortion of nature. Heidegger envisions living and working with, rather than against, natural processes. Hence he contrasts high-technology agribusiness to the work of the peasant, which "does not challenge the soil of the field. In the sowing of the grain [he] places the seed in the keeping of the forces of growth and watches over its increase" (Heidegger 1977b, 15). Unfortunately, Heidegger tends to romanticize the peasantry. He ignores the fact that small-scale farming may be every bit as intent on the unsustainable exploitation of land as large-scale operations. If the peasant proves less ecologically destructive, it may be owing only to the relatively small size of his enterprise. Indeed, to the extent that poverty forces peasants to cultivate smaller and smaller plots of land more intensively, environmental devastation looms. In any case, neither peasants nor business people are born with specifically ecological dispositions. Care for the land-and for people-must be fostered culturally. Heidegger is right in thinking that this care is fostered much better within small farming communities than within large-scale agribusiness bent on ungoverned technological growth. Still, we had best eschew the bucolic romanticism that Heidegger found irresistible; for the rootedness in soil that Heidegger longed for has a seamy political side. In its thrall one might, like Heidegger, succumb to a dangerous infatuation with the power of blood and soil that neatly aligns itself with fascism. In turn, agrarian provincialism may militate against environmental oversight on a global scale. Yet many of the most pressing environmental threats today remain impervious to anything but a globally regulated redress. In any case, the global management of certain ecological concerns does not necessarily disrupt our caring for community or bioregion. Indeed, the environmental slogan Think Globally, Act Locally is based on the general compatibility - even synergy-of global and local concerns. There are no eternal demarcations of one's place of dwelling. Rootedeness, for some, will pertain to a valley or watershed; for some, to a city or nation; and for some, to the earth itself. Heidegger's own preferences for Swabian peasant culture need not constrict our own habitat.

In concluding our critical exploration of Heidegger's ecological credentials, we must acknowledge that our relation to the earth will always entàil preservative as well as exploitative and destructive measures. At a minimum, we learn from Heidegger that a balance must be reestablished-a balance most obviously and most dangerously lost in the modern world. Ecological concerns have erupted in contemporary times largely as a result of the increasingly obvious limits to human growth. In effect, Heidegger offers us a philosophy of limits. He describes our freedom as dependent upon rather than curtailed by our worldly boundaries and horizons. With this in mind, disclosive freedom may well provide the necessary corrective to the frenzied technological activity that threatens the earth with its unbounded scope. 


\section{Sovereignty and the Politics of Public and Private}

In one of her most difficult essays, "What Is Freedom?" Hannah Arendt takes issue with traditional Western notions of liberty (1968, chap. 4). For Arendt, the nature of freedom has been obscured owing to prevailing philosophical concepts structuring the political realm. These concepts identify freedom as a function of (the mastery of) will. In contrast, Arendt observes the freedom is far from being the (will)power to achieve or control one's desires. She indicates (in all probability to the reader's confusion) that action, to be truly free, "must be free from motive on one side [and] from its intended goal as a predictable effect on the other" (p. 151). In direct opposition to the common notion of freedom as the opportunity to fulfill one's wants, Arendt strips from freedom both the final attainment of a goal and the initial motivations for its pursuit. The reason is that freedom, for Arendt, is less an individual achievement than a public event. Freedom is manifest in the open spaces of the political realm where the actions of citizens intersect. But action and interaction (as opposed to behavior) are inherently unstable and unpredictable. What humans discover when they act in concert is that freedom is manifest in the very novelty of the results. Far from being controllable and predictable, action, Arendt states, is closer to the nature of a miracle. In action, by way of freedom, the new and the unforeseen occurs.

The pursuit of sovereignty, which orients most Western political thinking about the individual and the state, is identified with the effort to achieve control over the outcome of action. Far from being the prerequisite for freedom, Arendt finds that sovereignty signals its demise:

Under human conditions, which are determined by the fact that not man but men live on the earth, freedom and sovereignty are so little identical that they cannot even exist simultaneously. Where men wish to be sovereign, as individuals or as organized groups, they must submit to the oppression of the will, be this the individual will with which I force myself, or the "general will" of an organized group. If men wish to be free, it is precisely sovereignty they must renounce. $(1968,165)$

Arendt's discussion of freedom is nothing if not shocking for the Western mind. I believe it is most fruitfully viewed as a political reconstruction of Heidegger's notion of disclosive freedom. Heidegger, like Arendt, indicates that freedom evaporates once it is possessed by a sovereign power. Indeed, freedom is not freedom until it possesses us. Like Arendt's conception, disclosive freedom is inherently antipodal to sovereignty and inherently unpredictable. It is revealing of the world and of the new.

Perhaps the aspect of Arendt's political thought most criticized is her distinction between the public and the private realms. We recall that for Arendt the public realm is the birthplace of freedom. Only in the political space devoted not to the necessities of existence but rather to the discovery and preservation of freedom is politics to be found and safeguarded.
Freedom therefore lies in stark and unbridgeable contrast to the continuing and unavoidable processes that sustain life in the darkness of privacy. Arendt claims that the divorce between freedom and necessity-the public and the private-is irreconcilable and complete. Anything that issues from life's needs cannot be considered the stuff of politics. The provision of services and goods, the maintenance of households and the exercise of administration, therefore pertains only to the realm of necessity. The public speaking of great words and doing of great deeds maintains a monopoly on freedom. Arendt has presented us with a stunning vision of politics. The wondrous novelty of birth she celebrates is revived in the heroic human capacity for political beginnings. The consequence of her position, however, is that everything that falls between the novelty of birth and the sporadic explosions of freedom evidenced in great speeches and deeds (i.e. the vast bulk of human life) is relegated to the unredeemable realm of necessity.

In the 1844 Manuscripts, Marx states that man separates himself from the animals by finding his freedom in production beyond physical need (1978, 76). Arendt, despite her virulent attack on Marx's designation of man as an animal laborans, effectively extends this enlightenment position. But freedom is now found not in the realm of surplus production but in what might be called the realm of surplus speech and action. Politics and freedom, for Arendt, are manifest only in that human capacity for novelty and creation of word and deed ungrounded in and distinct from the demands of everyday life. Maintenance and preservation, through labor, administration, and general caretaking, is the sorry if necessary task of the unfree. Arendt, like Foucault, celebrates contingency and dismisses sovereignty in the exercise of freedom. And Arendt, like Foucault, insists on the heroic nature of political life. Her standards of heroism, however, come directly from the Greeks rather than via Nietzsche. Consequently, Arendt's criteria for freedom, in contrast to Foucault's, shift from selfcreative to world-creative engagements. Nonetheless, her dismissal of the possibility of a freedom exercised in caretaking is equally unrelenting.

We observe that Heidegger's notion of disclosive freedom philosophically buttresses Arendt's political theorizing. Perhaps more importantly, his understanding may also remedy the shortcomings of Arendt's analysis. Arendt wishes to claim that the divorce between freedom and necessity-the public and the private-is irreconcilable and complete. Anything that speaks to the demanding necessities of life does not partake of freedom and ipso facto cannot be considered the stuff of politics. But as Heidegger demonstrates, freedom is evidenced whenever and wherever we open ourselves to the world of beings. Political freedom, then, is evidenced whenever speech and action disclose the world of beings, including our social being-in-the-world, publicly. There seems little reason to exclude from this category, as Arendt unfortunately does, most aspects of 
worldly life simply because they pertain to the unheroic realm of social, physical, or economic need. Changing a baby's diapers or the oil in one's car, going to the marketplace or out of town for a holiday, do not in themselves evidence much political freedom, to be sure. But the provision of day-care facilities and parental leave from work, the promulgation of laws for the mandatory recycling of motor oil, the regulation of the sales of goods according to health and environmental standards, and the provision and maintenance of transportation infrastructure are important political concerns. What makes something political-in these cases and in general-has less to do with whether it pertains to our (basic) needs than to whether and how these needs are collectively addressed and fulfilled. Politics, in other words, may be in evidence whenever the world of beings and the with-world of human beings remain open to public interrogation and disclosure. Political freedom, then, emerges most fundamentally in the caretaking of this public realm. And such caretaking, accomplished in words and deeds, is both preservative and creative in nature. Arendt teaches us that sovereignty, personal or national in scope, is antagonistic to freedom. In the same vein, Heidegger teaches us that grand words and deeds, if carried out in the willful and forgetful pursuit of mastery, may also preclude freedom's greatest exercise. In today's world, where the caretaking of local and global ecologies becomes an increasingly important task, such a Heideggerian understanding of freedom bears obvious political significance.

\section{Being, Doing, and Gender Identity}

The boundary between private and public realms is permeable, and the relationship between private and public realms is very much a political one. With this in mind, feminist theorists have offered sustained critical analyses of the ideological foundations of negative liberty. Liberalism, grounded in the concept of negative liberty, evidences an overriding concern for establishing boundaries between individuals in order to proscribe illegitimate interference. Consequently, liberals are primarily concerned with securing personal independence and rights. Many feminists claim that these concerns belie liberalism's masculinist tendencies, most evident in its neglect of what many describe as the predominantly (though not uniquely) feminine concern with establishing and maintaining relationships and community. Nancy Chodorow, relying on the work of feminist anthropologists, psychoanalysts, and object relations theorists, offers an explanation of this disjunction based on the early socialization of children. A girl's sexuality and sense of self, Chodorow theorizes, is "ascribed" to her through her relationship with her caretaker mother. She comes to understand her identity as expressive of her nature rather than explicitly dependent on a performative act. A boy, on the other hand, grows up in most societies with his same-sex parent much in absence and infrequently in the caretaker's role. His sexuality and sense of self are therefore much less the product of an identification with the nurturing parent. Rather, a boy's identity must be "achieved" in distinction from and perhaps in opposition to-the mother. Achieving a stable male identity becomes a matter of asserting independence from the caretaker mother in a defensive establishing of ego boundaries. Moreover, boys' socialization accentuates the performative character of the sexual act. Thus feminine identity is socialized as a being, Chodorow observes, while male identity, constantly in need of demonstration, is socialized as a doing.

The political ramifications of this psychology are not difficult to foresee. The marked differences in the development of male and female identities in early childhood produce a disjunctive and hierarchical social structure. Male values of independence, competitive achievement and aggressiveness oppose, dominate, and are reinforced by female values of dependence, caretaking, and passivity. Chodorow concludes that "until masculine identity does not depend on men's proving themselves, their doing will be a reaction to insecurity rather than a creative exercise of their humanity, and woman's being, far from being an easy and positive acceptance of self, will be a resignation to inferiority" $(1989,44)$. Chodorow's research has stimulated many popular works that question the psychological predispositions structuring our social and political lives (e.g., Gilligan 1982; Belenky et al 1986). Without affirming the suspect generalizations of these efforts, I would submit that their resonance with such a wide audience speaks to the increasing instability of traditional (liberal and patriarchal) understandings of political and social identity. The prevalent notions of (negative) liberty that ground these understandings evidence their limits.

Heidegger's understanding of freedom as a disclosive letting-be informs and buttresses this feminist psychology and political theorizing. In a patriarchal world that narrowly conceives freedom as sovereignty, relations of mastery will continue to delimit human identity and define human dignity. As long as our understanding of freedom is restricted to the exclusion of others from our personal space (or, as with positive liberty, to the mastery of ourselves and our world), then our politics will remain one in which the individual meets the world and the other in a singular struggle for self-assertion. Alternatively, if precisely our relatedness to the world and to others begets our freedom, then the struggle for understanding comes to fore. At this juncture, philosophy and psychology most clearly cross paths, and the cultural and political implications of transformed understandings of freedom and dignity emerge. I am suggesting that patriarchal culture will continue to infect politics to the extent that freedom is understood and exercised solely as a masterful, independent doing rather than a disclosive, interpretive way of being.

The practice of disclosive freedom will not obviate 
the interminable struggles of identity to which human beings are heir. The point is that these struggles may be waged interpretively, for understanding, as well as antagonistically, for mastery. The struggle for mastery need not entail an appreciation of the situated self, and seldom entails an understanding of the other, except insofar as it enables the other's exploitation. ${ }^{11}$ On the other hand, the struggle for understanding typically entails the disclosure of the self and the other in the context of a shared world. It follows that disclosive freedom - the medium of this interpretive struggle-entails rather than curtails in its own actualization the participation in freedom of that which lies beyond the self. In these terms, the significance of disclosive freedom for a democratic politics emerges.

\section{CONCLUSION}

Twenty-five hundred years ago Pericles admonished the Athenians in his Funeral Oration, "Make up your minds that happiness depends on being free, and freedom depends on being courageous" (Thucydides 1954, 149-50). In fifth-century Athens, freedom already had become the most cherished value. The pursuit of this value, however, quickly became a mask for imperial mastery. The development of Western freedom has evinced numerous variations of this theme. Hegel could write with typical aplomb that "the history of the world is none other than the progress of the consciousness of freedom" $(1956,19)$. Hegel was not mistaken in his assessment of the tenor of history, for he correctly discerned the historical origins of Western freedom in the dialectic of master and slave. ${ }^{12}$ At the end of history, Hegel announces, there is universal acknowledgement not that some are free and others in bondage but that man as such is free. And yet, firmly situated within the Western metaphysical tradition, Hegel could not see beyond its perimeter. Consequently, Hegel maintains that modern freedom is gained only by exchanging the mastery of some over the lives of others for humankind's presumed mastery over history itself.

The Western development of the consciousness of freedom, from its inception, remains in the service of such quests for mastery. Only the historical subjects and objects of domination change-from the domination of the master over the slave in ancient Greece, to that of the higher over the lower self with the Stoics, to Rousseau's (Marx's) romantic collectivization of this ideal in the reign of the general will (proletarian consciousness) over the individual, to liberalism's claim of the individual's sovereign control over a private realm, to postmodern mastery wherein the existence (let alone maintenance) of any such borders to the self are denied, while the ironic attempt is made to transform self-control into a full-fledged self-creation. I am proposing that we ponder a freedom no longer wedded to masterymastery being defined as willful control of the world, the other, a private domain, or the self (be that self understood as transcendental but repressed or awaiting its protean constitution).

Negative liberty is apt to degenerate into license and the breakdown of community; positive liberty, into tyranny and totalitarianism; postmodern liberty, into apathy and despair in the face of a ubiquitous web of power or (alternatively) into the isolated self-aggrandizement of one who in the face of inescapable normalization nihilistically embraces an unbounded self-invention. Disclosive freedom, no doubt, has its own pathologies and susceptibilities. Openness to the mystery of Being might degenerate into fatalism, the reining in of will might deteriorate into passivity before the powers that be. I am not proposing, then, that disclosive freedom wholly substitute for negative, positive, and postmodern liberties. Rather, the task is one of problematizing, supplementing, and perhaps sublimating their practise. Just as Berlin believes that positive liberty (as selfgovernment) should be viewed primarily as a means to protect negative liberty, so one might argue conversely that negative, positive, and postmodern liberties should be viewed as necessary means to protect and foster the conditions favorable to the exercise of disclosive freedom. And what Berlin concedes of positive liberty I would unbegrudgingly affirm for negative and postmodern liberties, as well: their exercise easily leads to dangerous abuses and perversions; yet held in balance they remain "essential for a decent existence." 13 Heidegger, unfortunately, was reluctant to make such concessions. Still, he does not completely impugn the practical worth of prevalent notions of freedom. Rather, he observes their limitations and notes specifically regarding negative and positive liberty and their Nietzschean alternative that disclosive freedom stands over and above them from a philosophic perspective.

I have insufficiently indicated the political implications of disclosive freedom. My sense is that its political implications are necessarily ambiguous. This ambiguity is, to be sure, unsettling. But we should not be dissuaded from the exploration and practise of disclosive freedom for that reason alone. Isaiah Berlin, in closing his essay on the two concepts of liberty, asserts that the principle underlying negative liberty-perhaps only the "late fruit of our declining capitalist civilization"-is no less valid because the duration of its historical ascendency can not be guaranteed $(1969,172)$. The "relative validity" of our convictions, Berlin insists, should not dissuade us from upholding them. Indeed, he maintains that it would be a sign of a dangerous political immaturity to demur in the face of such uncertainty. I submit that the decaying fruits of our ecologically declining civilization have germinated the seeds of a disclosive freedom. This freedom, properly cultivated, offers us dignity and stamina in the political struggle against the "unchecked momentum" and "irresistible pow$\mathrm{er}^{\prime \prime}$ of a technologically driven way of life. Whether disclosive freedom will find a foothold in the postmodern world and, if so, just what its historical role and longevity might be surely remains beyond our 
power to determine. But, like Berlin, I would argue that the convictions and experiences that underlie it, philosophical and worldly in nature, are on this count no less valid.

\section{Notes}

This paper was originally delivered at the 1992 American Political Science Association Annual Meeting in Chicago. I would like to thank my discussant, Stephen K. White, as well as Fred Dallmayr and other audience members for their comments. Funding for this paper was provided by the Social Science and Humanities Research Council of Canada.

1. I am not completely alone in this belief. Fred Dallmayr also finds that Heidegger's thought "from the earliest to the latest writings is permeated by the endeavor to grapple with the category of 'freedom' - in a manner that decisively moves beyond the confines of traditional liberalism and libertarianism" (1984, 207; see also Haar 1989).

2 . Berlin notes that in theory negative liberty might have similar psychological requirements, demanding knowledge of which self is not to be interfered with and constrained. Historically, however, this has seldom been the case. Those promoting negative liberty have simply identified the empirically demonstrative self as the true self. Hobbes offers the most straightforward example of this understanding: "Liberty, or Freedome, signifieth (properly) the absence of Opposition; (by Opposition, I mean externall Impediments of motion;) and may be applyed no lesse to Irrational, and Inanimate creatures, than to Rationall" (1968, 261-62)

3. Even John Stuart Mill, Berlin notes, is guilty on this count. Berlin's views on this issue have been hotly disputed. Many have straightforwardly concluded against him that "to give up, for the sake of justice some freedom to act is not to diminish liberty" (Reed 1980;376).

4. I take this characterization of Berlin's two concepts from Taylor 1979.

5. Connolly also worries that Heidegger facilitates his being taken prisoner by the "communitarian" camp, who see freedom as an "attunement" to the world (1991, 225). Heidegger's talk of attunement (Gestimmtsein), however, refers not to faith in the "higher direction" of nature or the cosmos but (as we shall see) to an appreciation of profound mystery.

6. Heidegger's turning, or Kehre, signals his shift from a focus on the heroic capacity of human being to disclose Being to a focus on human being's participatory relationship to Being's disclosure. In an insightful examination, Michel Haar (1989) suggests that human freedom becomes enveloped and overpowered by the "narcissism of Being" burgeoning in Heidegger's later writings. Haar's concern is based on the assumed equivalence of human autonomy and human freedom. However, once we accept that disclosive freedom is better described in terms of contextual participation than in terms of sovereign possession, Haar's worry about the "dispossession" of freedom by Being appears misplaced.

7. Jerry Weinberger (1992), like many others who are polemically engaged with Heidegger, mistakenly assumes that the technological stamping of the age is equivalent to a pessimistic technological determinism. Heidegger, however, turns the tables on those who make such charges. He writes, "All attempts to reckon existing reality morphologically, psychologically, in terms of decline and loss, in terms of fate, catastrophe, and destruction, are merely technological behavior" (Heidegger 1977b, 48).

8. In the same vein, Charles Taylor writes that "Heidegger's understanding of language, its telos, and the human essence can be the basis of an ecological politics, founded on something deeper than an instrumental calculation of the conditions of our survival (though that itself ought to be enough to alarm us). It can be the basis of in one sense a 'deep' ecology" (1992, 266).
9. Heidegger is frequently misinterpreted on this score (see, e.g., Devall and Sessions 1985, 99). A literal biocentrism, if conceivable in practice, would certainly be undesirable. The AIDS virus and the useful bacteria of our digestive tracts are most interesting specimens of life. But that we should cease to exploit the latter or combat the former seems to me as silly as it is unnatural. Nature, as Nietzsche was fond of reminding us, is all about exploitation and battles to the death, and we should not be arguing for a world in which viruses have the same "rights" to life and growth as children (see Thiele n.d.).

10. We read, for example: "That all functional relations are grounded ontologically in a for-the-sake-of in no way decides whether, ontically, all beings are as beings for the sake of the human Dasein" (Heidegger 1982, 295).

11. The best account of this dynamic that I am aware of is Todorov 1984.

12. One might argue that the Western valorization of freedom is primarily the product of slavery, that the value of freedom has developed out of the desire to escape the master's power. Hegel and Nietzsche both make this point in different ways with a respective historical and psychological intent. Recently (and with a sociological slant), Orlando Patterson has cogently reformulated the argument that "freedom was generated from the experience of slavery" (1991, xiii).

13. In a recent interview, Berlin states:

The only reason for which I have been suspected of defending negative liberty against positive and saying that it is more civilized is that I do think that the concept of positive liberty, which is of course essential to a decent existence, has been more often abused or perverted than that of negative liberty.... Certainly the weak must be protected against the strong. . . . Negative liberty must be curtailed if positive liberty is to be sufficiently realized; there must be a balance between the two, about which no clear principles can be enunciated.

\section{References}

Arendt, Hannah. 1968. Between Past and Future. New York: Penguin.

Belenky, Mary Field, Blythe McVicker Clinchy, Nancy Rule Goldberger, and Jill Mattuck Tarule. 1986. Women's Ways of Knowing: The Development of Self, Voice, and Mind. New York: Basic Books.

Berlin, Isaiah. 1969. Four Essays on Liberty. Oxford: Oxford University Press.

Berlin, Isaiah. 1992. "Philosophy and Life: An Interview; New York Review of Books, 28 May, pp. 52-53.

Blitz, Mark. 1981. Heidegger's "Being and Time" and the Possibility of Political Philosophy. Ithaca Cornell University Press.

Boswell, James. 1979. The Life of Samuel Johnson. New York: Penguin.

Butler, Judith. 1990. Gender Trouble: Feminism and the Subversion of Identity. New York: Routledge.

Chodorow, Nancy. 1989. Feminism and Psychoanalytic Theory. New Haven: Yale University Press.

Connolly, William, E. 1991. Identity Difference: Democratic Negotiations of Political paradox. Ithaca: Cornell University Press.

Cranston, Maurice. 1967. Freedom. New York: Basic Books.

Crews, Frederick. 1992. "The New Americanist." New York Review of Books, 24 September, p. 33.

$\rightarrow$ Dallmayr, Fred. 1984. "Ontology of Freedom: Heidegger and Political Philosophy." Political Theory 12:204-34.

Devall, Bill, and George Sessions. 1985. Deep Ecology: Living as if Nature Mattered. Salt Lake City: Smith.

Ferry, Luc, and Alain Renaut. 1990. Heidegger and Modernity. Trans. Franklin Philip. Chicago: University of Chicago Press.

Foucault, Michel. 1977. Language, Counter-memory, Practice. Trans. D. F. Bouchard. Ithaca: Cornell University Press, 1977.

Foucault, Michel. 1979. "Governmentality." Ideology and Consciousness 6:5-21.

Foucault, Michel. 1980. The Use of Pleasure. Vol. 2 of The 
History of Sexuality. Trans. Robert Hurley. York: Vintage Books.

Foucault, Michel. 1981. "Omnes et Singulatum: Towards a Critique of 'Political Reason'." In The Tanner Lectures on Human Values, vol. 2. ed. Sterling McMurrin. Salt Lake City: University of Utah Press.

Foucault, Michel. 1983. "On the Genealogy of Ethics: An Overview of Work in Progress." In Michel Foucault: Beyond Structuralism and Hermeneutics, 2nd ed., ed. Hubert Dreyfus and Paul Rabinow. Chicago: University of Chicago Press.

Foucault, Michel. 1984. The Foucault Reader. Ed Paul Rabinow. New York: Pantheon.

Foucault, Michel. 1985. "Final Interview." Raritan 5:1-13.

$\rightarrow$ Foucault, Michel. 1993. "About the Beginning of the Hermeneutics of the Self: Two Lectures at Dartmouth." Political Theory 21:198-227.

Gilligan, Carol. 1982. In a Different Voice: Psychological Theory and Women's Development. Cambridge: Harvard University Press.

Glausser, Wayne. 1990. "Three Approaches to Locke and the Slave Trade." Journal of the History of Ideas 51:199-216.

Haar, Michel. 1989. "The Question of Human Freedom in the Later Heidegger." The Southern Journal of Philosophy Suppl. 28:1-16.

Hegel, G. W. F. 1956. The Philosophy of History. Trans. J. Sibree. New York: Dover.

Heidegger, Martin. 1949. Existence and Being. Washington: Regnery Gateway.

Heidegger, Martin. 1962. Being and Time. Trans. J. Macquarrie and E. Robinson. New York: Harper \& Row.

Heidegger, Martin. 1968. What Is Called Thinking? Trans. J. Gray. New York: Harper \& Row.

Heidegger, Martin. 1969. Identity and Difference. Trans. J. Stambaugh. New York: Harper \& Row.

Heidegger, Martin. 1971. Poetry, Language, Thought. Trans. A. Hofstadter. New York: Harper \& Row.

Heidegger, Martin. 1975. Early Greek Thinking. Trans. D. Krell and F. Capuzzi. New York: Harper \& Row.

Heidegger, Martin. 1976-89. Gesamtausgabe. 65 Vols. Frankfurt am Main: Vittorio Klostermann.

Heidegger, Martin. 1977a. Basic Writings. New York: Harper \& Row.

Heidegger, Martin. 1977b. "The Question Concerning Technology" and Other Essays. Trans. William Lovitt. New York: Harper \& Row.

Heidegger, Martin. 1981. Nihilism. Vol. 4 of Nietzsche. Trans. Frank Capuzzi and David Krell. New York: Harper \& Row.

Heidegger, Martin. 1982. The Basic Problems of Phenomenology. Trans. Albert Hofstadter. Bloomington: Indiana University Press.

Heidegger, Martin. 1984. The Metaphysical Foundations of Logic.
Trans. Michael Heim. Bloomington: Indiana University Press.

Heidegger, Martin. 1985a. Schelling's Treatise on the Essence of Human Freedom. Trans. Joan Stambaugh. Athens: Ohio University Press.

Heidegger, Martin. 1985b. "The Self-Assertion of the German University and the Rectorate 1933/34: Facts and Thoughts." Review of Metaphysics 38:467-502.

Heidegger, Martin. 1987. An Introduction to Metaphysics. Trans. R. Manheim. New Haven. Yale University Press.

Hobbes, Thomas. 1968. Leviathan. Ed. C. B. Macpherson. New York. Penguin.

Locke, John. 1960. Two Treatises of Government. Ed. Peter Laslett. New York: Mentor.

Patterson, Orlando. 1991. Freedom in the Making of Western Culture. Vol 1 of Freedom. New York: Basic Books.

$\rightarrow$ Reed, Gary Frank. 1980. "Berlin and the Division of Liberty." Political Theory 8:365-80.

Ryan, Alan. 1979. The Idea of Freedom: Essays in Honour of Isaiah Berlin. Oxford: Oxford University Press.

Taylor, Charles. 1979. "What's Wrong with Negative Liberty?"' In The Idea of Freedom, ed. Alan Ryan. Oxford: Oxford University Press.

Taylor, Charles. 1992. "Heidegger, Language, and Ecology." In Heidegger: A Critical Reader, ed. Hubert Dreyfus. Cambridge: Blackwell.

$\rightarrow$ Thiele, Leslie Paul. 1986. "Foucault's Triple Murder and the Modern Development of Power." Canadian Journal of Political Science 19:243-60.

Thiele, Leslie Paul. 1990. "The Agony of Politics: The Nietzschean Roots of Foucault's Thought." American Political Science Review 84:907-25.

Thiele, Leslie Paul. 1991. "Reading Nietzsche and Foucault: A Hermeneutics of Suspicion?" American Political Science Review 84:907-25.

Thiele, Leslie Paul. N.d. "Nature and Freedom: A Heideggerian Critique of Biocentric and Sociocentric Environmentalism." Environmental Ethics. Forthcoming.

Thucydides. 1954. The Peloponnesian War. New York: Penguin. Todorov, Tzvetan. 1984. The Conquest of America: The Question of the Other. New York: Harper \& Row.

Weinberger, Jerry. 1992. "Politics and the Problem of Technology: An Essay on Heidegger and the Tradition of Political Philosophy." American Political Science Review 86:112-27.

Zimmerman, Michael. 1983. "Toward a Heideggerian Ethos for Radical Environmentalism." Environmental Ethics 5:99_ 131.

Zimmerman, Michael. 1990. Heidegger's Confrontation with Modernity: Technology, Politics, Art. Bloomington: Indiana University Press.

Leslie Paul Thiele is Assistant Professor of Political Science, University of Florida, Gainesville, FL 32611 